\section{Andrzej Piwowar}

Katolicki Uniwersytet Lubelski Jana Pawła II andpiw@gazeta.pl

DOI: http://dx.doi.org/10.12775/BPTh.2016.019

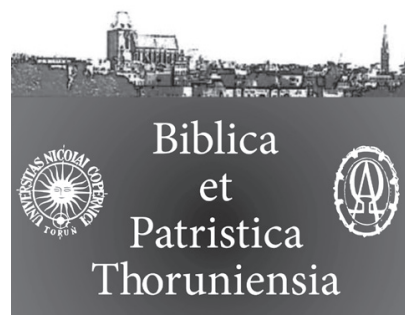

9 (2016) 2: 145-167

ISSN (print) 1689-5150

ISSN (online) 2450-7059

\title{
„Podnieś się i rzuć się w morze!" (Mk 11,23/Mt 21,21). Rzecz o powszechnym błędzie w tłumaczeniach polskich i jego teologicznych konsekwencjach
}

\author{
"Get up and throw yourself into the sea!" \\ (Mk 11:23/Mt 21:21). On a common mistake \\ in Polish translations and its theological consequences
}

Streszczenie. Artykuł poświęcony jest niewłaściwemu tłumaczeniu słów arthēti kai blèthēti eis tēn thalassan zawartych w Mk 11,23 i Mt 21,21 oraz ekridzōthēti kai fyteuthêti en tē $[i]$ thalassē $[i]$ (Łk 17,6). Formy czasownikowe wyrażone w tekście greckim za pomocą imperatywów strony biernej aorystu, zostały oddane we wszystkich polskich przekładach tłumaczeniach za pomocą strony zwrotnej („Podnieś się i rzuć się w morze"). Nie ma żadnych podstaw (ani semantycznych, ani syntaktycznych), aby właśnie w ten sposób oddać przetłumaczyć te słowa na język polski. Co więcej, oddanie ich za pomocą strony zwrotnej wypacza przesłanie teologiczne logionu, w którym są zawarte. Analizowane w artykule słowa powinny zostać oddane za pomocą trybu rozkazującego strony biernej, ponieważ stanowią passivum theologicum („Zostań podniesiona i [zostań] rzucona do morza"). Powyższa interpretacja jest wiernym tłumaczeniem tekstu oryginalnego, ponadto lepiej odpowiada kontekstowi, w którym logion Jezusa został przekazany przez ewangelistów, i jego przesłaniu teologicznemu. Artykuł jest także próbą wskazania przyczyn przekładu zawartego we wszystkich wydaniach Nowego Testamentu na język polski.

Abstract. The article is devoted to incorrect translations of the expression arthêti kai blèthêti eis tēn thalassan in Mk 11:23 and Mt 21:21 as well as ekridzöthēti kai fyteuthēti en tê $[i]$ thalassē $[i]$ (Lk 17:6). Aorist passive imperative forms that are present in the Greek text are rendered in all Polish translations as reflexive forms ("Get up and throw yourself into the sea!"). There are no grounds, either semantic or syntactic, that would justify such a translation of these words into Polish. What is more, the translation using a reflexive form distorts the theological message of the logion in which the phrases are included. The words analysed in this article should be translated with the use of a passive voice imperative as they constitute passivum theologicum ("Be removed and be cast into the sea"). This is a faithful translation of the original text which corresponds to 
the context in which Jesus's logion was conveyed to the evangelists and to the logion's theological message. The article is also an attempt to pinpoint the reasons for the incorrect translation present in all versions of the New Testament in Polish.

Słowa kluczowe: Mk 11,23; Mt 21,21; Łk 17,6; podnieś się; rzuć się w morze; passivum theologicum; wiara; modlitwa.

Keywords: Mk 11:23; Mt 21:21; Lk 17:6; get up; throw yourself into the sea; passivum theologicum; faith; prayer.

Tiektóre teksty biblijne wpisały się w świadomość wierzących tak głęboko, 1 że stały się, jeśli tak można powiedzieć, sztandarowe, tzn. z jednej strony, gdy mówimy o jakimś zagadnieniu teologicznym, przychodzą nam natychmiast na myśl, z drugiej zaś najlepiej obrazują problem, do którego się odnoszą, ponieważ zawierają w sobie jego istotę - najważniejszą treść lub element poruszanego zagadnienia. Z całą pewnością jednym z takich tekstów dotyczących wiary jest logion zawarty w Mk 11,23: „Zaprawdę, powiadam wam: Kto powie tej górze: 'Podnieś się i rzuć się w morze', a nie zwątpi w duszy, lecz wierzy, że spełni się to, co mówi, tak mu się stanie” (tłumaczenie za Biblią Tysiąclecia). Tekst ten wyraża przekonanie, że jeśli ktoś naprawdę wierzy, to dzięki swej wierze może uczynić rzeczy niemożliwe, czego przykładem jest przeniesienie góry. Innymi słowy, wszystko jest dla niego możliwe. Już w samym Nowym Testamencie możemy dostrzec odniesienia do tego logionu (por. Mt 21,21; 17,20; Łk 17,6; 1 Kor 13,2 i Jk 1,6) ${ }^{1}$.

Celem niniejszego artykułu nie będzie analiza egzegetyczno-teologiczna Mk 11,23 i teksów paralelnych (por. Mt 21,21) ani ich Sitz im Leben ${ }^{2}$, ani tym bardziej kwestia synoptyczna. Zwrócimy natomiast uwagę na niewłaściwe tłumaczenie tegoż tekstu, a dokładniej mówiąc, jego części (słów „Podnieś się i rzuć się w morze”), we wszystkich polskich wydaniach Nowego Testamentu i ukażemy jego konsekwencje teologiczne. Aby osiągnąć zamierzony cel, przedstawimy najpierw kontekst bliższy Mk 11,23 i Mt 21,21. Następnie dokonamy analizy składniowej każdego z tych tekstów i wskażemy poprawny przekład słów, które są przedmiotem niniejszego artykułu. W dalszej części naszych rozważań nawiążemy do tekstu Łk 17,6, w którym możemy zaobserwować zjawi-

1 Zob. C.W. Hedrick, On Moving Mountains. Mark 11,22b-23/Matt 21,21 and Parallels, s. 219.

2 Zob. J. Duplacy, La foi qui déplace les Montagnes (Mt., XVII, 20; XXI, 21 et par.), s. 274-287; C.W. Hedrick, On Moving Mountains, s. 274-275; D. Ellul, Dérives autour d'un figuier: Matthieu 21,18-22, s. 69-76. 
sko analogiczne, zarówno z punktu widzenia składni tekstu greckiego, jak i jego tłumaczenia na język polski, do tego, które spotykamy w Mk 11,23 i Mt 21,21. Ukażemy także konsekwencje teologiczne błędnego przekładu i znaczenie poprawnego oddania słów greckich na język polski. W zakończeniu zaś postaramy się wskazać źródło niewłaściwej translacji na język polski tekstów, które są przedmiotem naszych analiz.

\section{Kontekst bliższy Mk 11,23 i Mt 21,21}

Mk 11,23 jest częścią perykopy Mk 11,20-25, która jest kontynuacją Mk 11,12$-14^{3}$. Obie jednostki rozdzielone są opowiadaniem, którego tematem jest oczyszczenie świątyni przez Jezusa i wyrzucenie ze świątyni jerozolimskiej sprzedających zwierzęta na ofiarę oraz bankierów zajmujących się wymianą monet (Mk 11,15-19) . W Mk 11,14 Jezus wypowiedział życzenie (forma fagoi jest optativem aorystu czasownika esthiō), aby drzewo figowe, na którym spodziewał się znaleźć jakieś owoce, ale ich na nim niestety nie było, już więcej nie wydało żadnego owocu. Następnego dnia rano, gdy Jezus wraz z uczniami przechodził obok owego figowca, Piotr zauważył, że drzewo to uschło całkowicie, aż do korzeni (Mk 11,20). Wyraził zdziwienie tym faktem (Mk 11,21), na co Jezus, odpowiadając, wezwał swych uczniów, aby mieli wiarę (Mk 11,22b; A. Yarbro Collins odkreśla ten werset jako nagłówek - tytuł dalszych słów Jezu$\left.\mathrm{sa}^{5}\right)^{6}$. To właśnie ona jest głównym tematem dwóch następnych wersetów (ww. 23-24) ${ }^{7}$. W końcowym wierszu perykopy (Mk 11,25) Jezus, kontynuując temat modlitwy, który został wprowadzony przez Niego w w. 24, wzywa apostołów do przebaczenia na wzór Ojca, który wybacza wszystkie grzechy. Głównym przesłaniem Mk 11,20-25 jest więc wezwanie do wiary, dzięki której człowiek wierzący może dokonać niezwykłych rzeczy, które przekraczają jego możliwości.

Mt 21,21 posiada podobny kontekst do Mk 11,23 ${ }^{8}$. Należy jednak zaznaczyć, że Mateuszowa wersja opowiadania o drzewie figowym, na którym Je-

3 Zob. M.D. Hooker, A Commentary on The Gospel according to St. Mark, s. 268-269.

4 Zob. J. Zmijewski, Der Glaube und Seine Macht. Eine traditionsgeschichtliche Untersuchung zu Mt 17,20; 21,21; Mk 11,23; Lk 17,6, s. 82.

5 Zob. A. Yarbro Collins, Mark, s. 533.

6 Zob. M.D. Hooker, A Commentary on The Gospel according to St. Mark, s. 269.

7 Zob. R.H. Stein, Mark, s. 519.

8 Zob. J.D.M. Derret, Moving Mountains and Uprooting Trees (Mk 11:22; Mt 17:20, 21:21; Lk 17,6), s. 234; J. Duplacy, La foi qui déplace les Montagnes (Mt., XVII, 20; XXI, 21 et par.), s. 274. 
zus nie znalazł żadnego owocu, aby móc się posilić, podkreśla sposób, w jaki ono uschło - niezwykle szybko. Mt 21,19d zaznacza, że drzewo natychmiast (parachrēma) stało się suche (eksēranthē forma strony biernej aorystu czasownika ksērainō, która posiada jednak znaczenie czynne). Natychmiastowy skutek słów Jezusa spowodował zdziwienie apostołów, tak że spytali, jak mogło się to tak szybko stać (Mt 21,20). Tak samo jak w Markowej wersji tego opowiadania, również w Mt 21,21 Jezus przypisuje to, co się wydarzyło na oczach Jego uczniów, wierze, zapewniając ich, że jeśli będą mieli wiarę, to nawet góry będą mogli przenosić (Mt 21,21). Co więcej, jeśli tylko będą naprawdę wierzyli, otrzymają wszystko, o cokolwiek tylko poproszą w modlitwie przepełnionej wiarą (Mt 21,22).

Zależność wersji Mateuszowej od Markowej jest widoczna i nie podlega żadnej wątpliwości ${ }^{9}$. Mateusz połączył jednak dwie perykopy Markowe (Mk 11,12-14 i Mk 11,20-25) w jedno opowiadanie. Dzięki temu zabiegowi redakcyjnemu podkreślił niezwykły fakt, że figowiec usechł natychmiast. To zdumiewające wydarzenie Jezus przypisuje wierze i wykorzystuje je do wyrażenia nauki o niewyobrażalnej mocy wiary, dla której wszystko jest możliwe, nawet przemieszczenie góry, która w Biblii jest symbolem stałości i trwałości ${ }^{10}$. C.W. Hedrick twierdzi, że Mk 11,23 odnosi się do modlitwy, która wypływa z głębokiej wiary ${ }^{11}$, zaś Mt 21,21 odnosi się bezpośrednio do cudu spowodowanego wiarą ${ }^{12}$. D.J. Harrington uważa jednak, że zarówno Markowy, jak i Mateuszowy tekst służą do wskazania siły modlitwy ${ }^{13}$.

9 Zob. W.D. Davies, D.C. Allison, The Gospel according to Saint Matthew III, s. 147; R.H. Gundry, Matthew, s. 417-418; A. Paciorek, Ewangelia wedtug świętego Mateusza. Część II: Rozdziaty 14-28, s. 324-325. Na temat historii rozwoju i oryginalności logionu zob. J.D. Crossan, In Fragments: The Aphorisms of Jesus, s. 295-307; J.D.M. Derret, Moving Mountains and Uprooting Trees (Mk 11:22; Mt 17:20, 21:21; Lk 17,6), s. 233; J. Duplacy, La foi qui déplace les Montagnes (Mt., XVII, 20; XXI, 21 et par.), s. 274; F. Hahn, Jesu Wort vom bergeversetzenden Glauben, s. 150-169; C.W. Hedrick, On Moving Mountains, s. 219-223; L. Morris, The Gospel according to Matthew, s. 531; J. Nolland, The Gospel of Matthew, s. 852; S. Schulz, Q die Spruchquelle der Evangelisten, s. 465-468; J. Zmijewski, Der Glaube und Seine Macht, s. 81-101.

10 Zob. R.H. Gundry, Mark, s. 649; E. Jezierska, Jaka wiara może "góry przenosić"? (Mt 17,14-21 i par.), s. 358-359; L. Ryken, J.C. Wilhott, T. Longman III (ed.), Le immagini bibliche. Simboli, figure retoriche e temi lettarari della Bibbia, s. 902.

11 Zob. F. Hahn, Jesu Wort vom bergeversetzenden Glauben, s. 150.

12 Zob. C.W. Hedrick, On Moving Mountains, s. 220.

13 Zob. D.J. Harrington, The Gospel of Matthew, s. 297. 


\section{Tekst Mk 11,23 i Mt 21,21 oraz ich analiza składniowa}

Tekst grecki Mk 11,23 brzmi następująco: amēn legō hymin hoti hos an eipē [i] tō [i] orei toutō [i]: arthèt $i$ kai blèthèti eis tèn thalassan, kai mè diakrithè [i] en tè [i] kardia[i] autou alla pisteué[i] hoti ho lalei ginetai, estai auto[i].

Logion Jezusa jest poprzedzony formułą, która $\mathrm{z}$ jednej strony stanowi uroczyste wprowadzenie dalszej części wersetu, z drugiej zaś jest zapewnieniem, że to, co zostanie powiedziane, jest prawdą pewną i niezawodną (amēn legō hymin $\left.{ }^{14}\right)$. Początkowa część wersetu, która jest wprowadzeniem do głównej wypowiedzi Jezusa, jest zakończona hoti. Słowo to w kontekście analizowanego przez nas tekstu może posiadać podwójne znaczenie. Po pierwsze, może wprowadzać mowę zależną („Zaprawdę mówię wam, że...”). Po wtóre może pełnić rolę tzw. hoti recitativum, tzn. być znakiem wprowadzającym mowę niezależną, który $\mathrm{w}$ tłumaczeniu możemy wyrazić za pomocą dwukropka („Zaprawdę mówię wam:”). Dalszą część wersetu, która w zależności od interpretacji hoti może być zarówno mową zależną, jak i niezależną, stanowi zdanie względne nieokreślone ${ }^{15}$, które bywa nazywane również zdaniem względnym warunkowym ${ }^{16}$. W swej budowie przypomina ono zdanie warunkowe typu eventualis, zwane także probablilitatis, które zamiast początkowego ean (,jeśli”), zostaje wprowadzone przez formułę uogólniającą hos an („ktokolwiek”). Poprzednik tego zdania względnego warunkowego składa się z trzech części. Pierwsza zawiera słowa: eipē [i] tō [i] orei toutō [i]: arthēti kai blèthèti eis tēn thalassan. Właściwym członem pierwszego poprzednika są słowa: eipē $[i]$ tō[i] orei toutō[i]. Dalsza jego część (arthēti kai blēthēti eis tēn thalassan) zawiera treść wypowiedzi wyrażonej w mowie niezależnej skierowanej do góry. Drugi segment poprzednika stanowią słowa kai mē diakrithē $i]$ en tē [i] kardia[i] autou. Jest on połączony z pierwszym za pomocą spójnika łączącego kai. Dwie pierwsze części poprzednika stanowią więc dwa warunki wzajemnie się uzupełniające. Trzecią częścią przesłanki zdania warunkowego zawartego w Mk 11,23 są słowa: alla pisteuē $i]$ hoti ho lalei ginetai. Są one połączone z poprzednimi częściami warunku za pomocą spójnika przeciwstawnego (alla), stanowią więc przeciwieństwo w stosunku do treści w nich

14 Zob. D.A. Hanger, Matthew 14-28, s. 606; A. Paciorek, Ewangelia wedtug świętego Mateusza. Część II: Rozdziały 14-28, s. 328; H. Schlier, amēn, s. 336.

15 Zob. K.L McKay, A New Syntax of the Verb in New Testament Greek, s. 154; E. de Witt Burton, Syntax of the Moods and Tenses in New Testament Greek, s. 116.

16 Zob. F. Blass, A. Debruner, Grammatica del greco del Nuovo Testamento, §380; R.A. Young, Intermediate New Testament Greek, s. 231. 
zawartych. Trzecia część protasis (poprzednika) zdania warunkowego, które analizujemy, składa się z dwóch członów: właściwego poprzednika oraz zdania dopełnieniowego (ho lalei ginetai) wprowadzonego przez hoti ${ }^{17}$. Musimy zwrócić uwagę, że w zdaniu dopełnieniowym zawartym w trzeciej części poprzednika występują dwa czasowniki w czasie teraźniejszym: lalei i ginetai. O ile pierwszy z nich stanowi właściwy czas teraźniejszy, to drugi powinniśmy określić jako praesens pro futuro, tzn. odnosi się do czynności przyszłej ${ }^{18}$. Ten rodzaj czasu teraźniejszego wyraża pewność, że czynność określona za jego pomocą zostanie zrealizowana w najbliższej przyszłości. Następnikiem analizowanego przez nas zdania warunkowego są słowa: estai auto[i]. Dativus zaimka osobowego powinniśmy określić jako dativus commodi (wyraża korzyść osoby, do której odnosi się zaimek) ${ }^{19}$.

Analizując, na podstawie budowy zdania warunkowego typu eventualis, zdanie warunkowe względne zawarte w Mk 11,23 musimy zwrócić uwagę na użycie w nim trybów i czasów, które determinują, czy zdanie to odnosi się do teraźniejszości czy też do przyszłości. W dwóch pierwszych częściach poprzednika występują czasowniki wyrażone w coniunctivus aoristi (eipē $\bar{e}$ i] i mé diakrithē[i]), powinniśmy zatem spodziewać się, że również w trzeciej części przesłanki będzie czasownik wyrażony za pomocą tego samego trybu i czasu. W trzecim członie protasis występuje jednak czasownik w koniunktiwie czasu teraźniejszego zamiast aorystu. Być może jest to spowodowane faktem, że autor chciał podkreślić, iż wymóg zawarty w trzeciej części poprzednika posiada charakter stały, niezmienny, ogólny, dlatego użył koniunktiwu czasu teraźniejszego zamiast aorystu. Ze względu na powyższe zaburzenie struktury zdania warunkowego możemy określić je jako zdanie warunkowe mieszane. W następniku występuje czas przyszły (estai). Powyższa struktura zdania względnego warunkowego zawartego w Mk 11,23 świadczy o tym, iż odnosi się ono raczej do przyszłości, niż do teraźniejszości.

17 Zob. J. Zmijewski, Der Glaube und Seine Macht, s. 82.

18 Zob. F. Blass, A. Debruner, Grammatica del greco del Nuovo Testamento, §323; R.H. Gundry, Mark, s. 649; A.T. Robertson, A Grammar of the Greek New Testament in the Light of Historical Research, s. 881-882; D.B. Wallace, Greek Grammar Beyond the Basics, s. 535-537; M. Zerwick, Il greco del Nuovo Testamento, $\$ 278$.

19 Zob. F. Blass, A. Debruner, Grammatica del greco del Nuovo Testamento, \$188; A.T. Robertson, A Grammar of the Greek New Testament in the Light of Historical Research, s. 538-539; D.B. Wallace, Greek Grammar Beyond the Basics, s. 142-144; M. Zerwick, Il greco del Nuovo Testamento, \$55-56. 
W strukturze Mt 21,21 możemy dostrzec zarówno podobieństwa do Mk 11,23, jak i różnice ${ }^{20}$. Tekst tego wersetu w języku greckim brzmi następująco: apokritheis de ho Iesous eipen autois: amēn legō hymin, ean echēte pistin kai mè diakrithète, ou monon to tēs sykē poièsete, alla kan tō[i] orei toutō[i] eipète: arthèti kai blèthèti eis tèn thalassan, genèsetai. Werset zaczyna się stwierdzeniem (apokritheis de ho Iesous eipen autois), że główna część zdania została wypowiedziana jako odpowiedź skierowana do uczniów. Jest ona wyrażona w mowie niezależnej i podobnie jak w Mk 11,23 posiada formę zdań warunkowych typu, które ze względu na spójnik wprowadzający je (ean) i ich budowę, moglibyśmy określić jako eventualis. Wersja Mateuszowa logionu Jezusa różni się jednak od Markowej tym, że wypowiedź Jezusa składa się z dwóch zdań warunkowych ${ }^{21}$, podczas gdy wersja Markowa zawierała jedno zdanie warunkowe choć z rozbudowanym (złożonym z trzech części) poprzednikiem. Również w Mt 21,21, podobnie jak w Mk 11,23, Jezus używa uroczystej formuły wprowadzającej amēn legō hymin, po której następują dwa zdania warunkowe. Pierwsze $\mathrm{z}$ nich wprowadzone przez spójnik ean posiada dwa poprzedniki: echète pistin i mē diakrithēte. Następnikiem pierwszego zdania warunkowego jest ou monon to tēs sykē poiēsete. Musimy zwrócić uwagę na budowę tego zdania warunkowego. Zostało ono wprowadzone przez ean, co przemawia za tym, iż mamy do czynienia ze zdaniem warunkowym typu eventualis. Jednak analiza jego części składowych wskazuje, że w poprzednikach mamy najpierw coniunctivus (echēte) i aoristi (mē diakrithēte), zaś w następniku tryb oznajmujący czasu przyszłego. Mamy więc do czynienia ze zdaniem warunkowym mieszanym. Ze względu na drugą część poprzednika i następnik powinniśmy uznać chyba, że odnosi się ono do przyszłości. Przemawia za tym także budowa drugiego zdania warunkowego. Zostało wprowadzone przez spójnik kan, który jest połączeniem kai z ean. W poprzedniku występuje coniunctivus aoristi (eipète), a w następniku indicativus futuri (genèsetai). Budowa tego zdania jednoznacznie określa, że jego treść odnosi się do przyszłości. Podobnie jak w Mk 11,23, również w tym zdaniu w przesłance mamy wyrażone w formie mowy niezależnej

20 „Matt 21:21, on the other hand, collapses the two saying within one conditional statement, condenses Mark's statement on not doubting into one line ('If you have faith and never doubt'), leads with it, and ties the entirely recast saying into the context by an appropriate reference to the fig tree ('you will not only do what has been done to this fig tree')" (C.W. Hedrick, On Moving Mountains, s. 230). Por. J. Zmijewski, Der Glaube und Seine Macht, s. 84.

21 J. Zmijewski twierdzi, że werset ten zbudowany jest w inny sposób: „Die Apodosis besteht aus zwei Gliedern (ou monon ... poiēsete, alla... genēsetai), deren zweites noch durch einen eingeschobenen Bedingungssatz (kan... eipète...) erweitert ist" (J. Zmijewski, Der Glaube und Seine Macht, s. 84). 
te same słowa, z którymi moglibyśmy zwrócić się do góry: arthēti kai blēthēti eis tèn thalassan.

Mówiąc o różnicach pomiędzy Mk 11,23 i Mt 21,21, powinniśmy podkreślić, że w tekście Markowym czasowniki występują w trzeciej osobie liczby pojedynczej, co sprawia, że logion Jezusa posiada charakter uniwersalny - odnoszący się do każdego człowieka. W Mt 21,21 czasowniki są wyrażone w drugiej osobie liczby mnogiej, ponieważ słowa Jezusa są zwrócone bezpośrednio do uczniów (stanowią odpowiedź na ich pytanie).

W obu tekstach słowa skierowane do góry, które wyrażają wiarę (przedmiot analiz niniejszego artykułu), są identyczne: arthèti kai blèthèti eis tèn thalassan. Powinniśmy zwrócić uwagę, że obie formy czasownikowe, które są przedmiotem naszych dalszych analiz i rozważań (arthèti i blèthèti), są wyrażone za pomocą drugiej osoby liczby pojedynczej imperatywu aorystu strony biernej.

\section{Niewłaściwe tłumaczenie}

Interesujące nas słowa (arthēti kai blèthēti eis tēn thalassan), które mają wyrażać moc wiary, we wszystkich polskich wydaniach Nowego Testamentu zostały oddane za pomocą strony zwrotnej. Mk 11,23 został przetłumaczony w najważniejszych przekładach polskich w następujący sposób:

„Zaprawdę, powiadam wam: Kto powie tej górze: 'Podnieś się i rzuć w morze', a nie zwątpi w duszy, lecz wierzy, że spełni się to, co mówi, tak mu się stanie" (Biblia Tysiąclecia);

„Zapewniam was: Jeśli ktoś powie tej górze: «Podnieś się i rzuć się w morze», a nie będzie powątpiewał w sercu, lecz wierzy, że to, co mówi, spełni się, to tak się mu stanie (Biblia Paulistów);

„Zaprawdę powiadam wam: Jeśliby ktoś powiedział tej górze: podnieś się i rzuć w morze, a nie wątpi w to, ale wierzył, że stanie się to, co mówi, tak też będzie" (Biblia Poznańska);

„Amen mówię wam, że który powie górze tej: Podnieś się i rzuć się w morze, i nie zawaha się w sercu jego, ale będzie wierzył, że co mówi, staje się, będzie mu” (Wydanie Interlinearne; red. R. Popowski - M. Wojciechowski);

„Zaprawdę mówię wam, jeśli ktoś powie tej górze: Powstań i rzuć się do morza i nie będzie przy tym żadnego wątpienia w jego sercu, że spełni się to, czego żąda to tak się stanie" (Biblia warszawsko-praska);

„Zapewniam was, że kto powie tej górze: Unieś się i rzuć w morze, a nie zwątpi w swoim sercu, lecz będzie wierzył, że to, co mówi się stanie, to tak będzie" (Pismo Święte Nowego Testamentu i Psalmy. Przekład ekumeniczny); 
„Zaprawdę powiadam wam: Ktokolwiek by rzekł tej górze: Wznieś się i rzuć się w morze, a nie wątpiłby w sercu swoim, lecz wierzył, że stanie się to, co mówi, spełni się" (Wydanie Brytyjskiego i Zagranicznego Towarzystwa Biblijnego $)^{22}$.

Jedynie Ewangeliczny przekład interlinearny Biblii tłumaczy poprawnie ten werset: „Amen [zaprawdę] mówię wam, że którykolwiek powiedziałby górze tej: Zostań podniesiona i zostań wrzucona w morze i nie zostałby wprowadzony w niepewność w sercu jego, ale uwierzyłby, że co mówi staje się, będzie mu, co jeśli powiedziałby".

W podobny sposób został oddany na język polski również tekst grecki Mt 21,21:

„Jezus im odpowiedział: «Zaprawdę, powiadam wam: Jeśli będziecie mieć wiarę, a nie zwątpicie, to nie tylko $\mathrm{z}$ figowcem to uczynicie, ale nawet gdy powiecie tej górze: 'Podnieś się i rzuć w morze', [tak] się stanie" (Biblia Tysiąclecia);

„A Jezus powiedział: «Zapewniam was: Jeśli będziecie mieć wiarę, a nie zwątpicie, nie tylko z drzewem figowym będziecie tak czynić, ale nawet gdy powiecie tej górze: 'Podnieś się i rzuć się w morze!', tak się stanie" (Biblia Paulistów);

„A Jezus odpowiedział: Zaprawdę powiadam wam: Jeśli będziecie mieli wiarę niezachwianą, zrobicie nie tylko to, [co zrobiłem] z tą figą, ale kiedy powiecie tej górze: Unieś się i rzuć się do morza - to tak się stanie" (Biblia Poznańska);

„Odpowiadając zaś Jezus rzekł im: Amen mówię wam: Jeśli mielibyście wiarę i nie zawahalibyście się, nie tylko to (z) figą uczynicie, ale i jeśli górze tej rzeklibyście: Unieś się i rzuć się w morze, stanie się" (Wydanie Interlinearne; red. R. Popowski - M. Wojciechowski);

„A Jezus odpowiedział: Zaprawdę mówię wam: jeśli będziecie mieli wiarę silną, będziecie mogli dokonać nie tylko tego, czego Ja dopiero co dokonałem $\mathrm{z}$ tą figą, ale nawet gdy powiecie tej górze: Podnieś się i rzuć się do morza, to tak się stanie" (Biblia warszawsko-praska);

„Jezus im odpowiedział: Zapewniam was, jeżeli będziecie mieli niezachwianą wiarę, nie tylko $\mathrm{z}$ drzewem figowym to uczynicie, ale nawet jeśli tej górze powiecie: Unieś się i rzuć w morze, to tak się stanie" (Pismo Święte Nowego Testamentu i Psalmy. Przekład ekumeniczny);

22 W podobny sposób werset ten przetłumaczony został przez Pismo Święte w Przekładzie Nowego Świata (wydanie Biblii dokonane przez świadków Jehowy na podstawie New Word Translation of the Holy Scriptures). 
„A Jezus, odpowiadając, rzekł im: Zaprawdę powiadam wam, jeślibyście mieli wiarę i nie wątpili, nie tylko to, co się stało z drzewem figowym, uczynicie, ale gdybyście i tej górze rzekli: Wznieś się i rzuć do morza, stanie się tak” (Wydanie Brytyjskiego i Zagranicznego Towarzystwa Biblijnego) ${ }^{23}$.

Natomiast ewangeliczny przekład interlinearny Biblii tłumaczy ten werset w następujący sposób: „Odpowiedziawszy zaś, Jezus powiedział im: Amen [zaprawdę] mówię wam, jeśli mielibyście wiarę i nie zostalibyście wprowadzeni w niepewność nie jedynie tylko (to) figowcowi uczynicie, ale jeśli górze tej powiedzielibyście: Zostań podniesiona i zostań wrzucona w morze, stanie się".

Z podanych przykładów wyraźnie i jednoznacznie widać, że imperatywy aorystu strony biernej (arthēti kai blēthèti) zostały przetłumaczone tak, jakby były w stronie medialnej bezpośrednio zwrotnej ${ }^{24}$, tzn. tak, jakby to góra miała sama z siebie wykonać obie czynności - sama miałaby się podnieść i sama miałaby się rzucić do morza. Przekład „Podnieś się i rzuć się w morze”25 idealnie odpowiada stronie medialnej bezpośrednio zwrotnej, która jednak nie występuje w tekście oryginalnym. W tekście greckim oba imperatywy zostały wyrażone nie w stronie medialnej, lecz biernej. Powinniśmy je zatem oddać poprzez:

23 W podobny sposób werset ten przetłumaczony został przez Pismo Święte w Przekładzie Nowego Świata (wydanie Biblii dokonane przez świadków Jehowy na podstawie New Word Translation of the Holy Scriptures).

24 Zob. D.B. Wallace, Greek Grammar Beyond the Basics, s. 416-418; M. Zerwick, Il greco del Nuovo Testamento, \$232-233.

25 W ten sam sposób lub podobny tekst ten jest tłumaczony w: G.J. Albrecht, M.J. Albrecht, Matthew, s. 399; T. Beck, U. Benedentti, G. Brambillasca, F. Clerici, S. Fausti, Una comunitá legge Il vangelo di Marco, II, s. 172; C.L. Blomberg, Matthew, s. 316; J.M. Boice, The Gospel of Matthew. Volume 2: The Triumph of the King. Matthew 18-28, s. 452; R.A. Cole, Il Vangelo secondo Marco. Intorduzione e commentario, s. 322; J.D.M. Derret, Moving Mountains and Uprooting Trees (Mk 11:22; Mt 17:20, 21:21; Lk 17,6), s. 234; J. Ernst, Il Vangelo secondo Marco, s. 532; R. Fabris, Matteo, s. 433; J. Gnilka, Das Evangeliu nach Markus. 2 Teil Mk 8,27-16,20, s. 132; Tenże, Das Matthäusevangelium. II Teil. Kommentar zu Kap 14,1-28,20 und Einleitungsfragen, s. 211; S. Grasso, Il Vangelo di Matteo, s. 496; Tenże, Vangelo di Marco, s. 271; J. Homerski, Ewangelia wedłu św. Mateusza, s. 289; R.J. Kernaghan, Mark, s. 219; E. Klostermann, Das Matthäusevengelium, s. 168; H. Langkammer, Ewangelia według św. Marka, s. 268; S. Légasse, Marco, s. 585; R. Meynet, Lévangeli de Marc, s. 377.379; G. Nolli, Evangelo secondo Marco, 287; Tenże, Evangelo secondo Matteo, 607; J. Radermarkers, Lettura pastorale del Vangelo di Matteo, s. 76; A. Paciorek, Ewangelia wedtug świętego Mateusza. Część II: Rozdziały 14-28, s. 324; A. Sand, Das Evangelium nach Matthäus, s. 425; E. Schweizer, Das Evangelium nach Markus, s. 126; H.E. Wicke, Mark, s. 159 . 
„Zostań podniesiona i zostań rzucona do morza”26. Jak uzasadnić translację powyższych słów na język polski? B.M. Newman twierdzi, że pomimo iż analizowane przez nas formy są w stronie biernej, to jednak dla czytelnika przetłumaczenie ich za pomocą form strony zwrotnej jest bardziej zrozumiałe ${ }^{27}$. Podobnie uważają także R.G. Bratcher i E.A. Nida. Ich zdaniem, pomimo iż arthêti kai blèthêti posiadają formę strony biernej, to jednak prawdopodobnie mają znaczenie strony medialnej ${ }^{28}$. Niestety, cytowani uczeni nie podają żadnego argumentu przemawiającego za ich interpretacją. Najprawdopodobniej sugerują się kontekstem, w którym występują analizowane przez nas słowa, lub istniejącymi już przekładami, które oddały analizowane przez nas słowa za pomocą strony zwrotnej.

Jedyną gramatyką greki Nowego Testamentu, która próbuje uzasadnić tłumaczenie arthèti kai blèthèti za pomocą strony zwrotnej, jest Greek Grammar Beyond the Basics. An Exegetical Syntax of the New Testament autorstwa D.B. Wallace’a ${ }^{29}$. Należy podkreślić, że jedynie ten podręcznik do składni języka greckiego Nowego Testamentu zwraca uwagę na formy strony biernej arthēti

26 Poprawnie, tzn. przy użyciu strony biernej Mk 11,23 i Mt 21,21 tłumaczą: W.F. Albright i C.S. Mann („Be rotted up and thrown into the sea”; W.F. Albright, C.S. Mann, Matthew. Introduction, Translation, and Notes, s. 259), M.E. Boring („be taken up and be cast into the sea”; M.E. Boring, Mark, s. 317); R.G. Bratcher, E.A. Nida („you be taken up and cast”; R.G. Bratcher, E.A. Nida, Mark, s. 355); W. Carter („Be lifted up and thrown into the sea”; W. Carter, Matthew and the Margins, s. 422); J. Delorme („sois enlevée et sois jetée dans la mer"; J. Delorme, L’heureuse annonce selon Marc. Lecture intégrale du deuxième évangile II, s. 224); C.A. Evans („Be and be cast into the sea”; C.A. Evans, Mark 8:27-16:20, s. 184.189); R.T. France („Up with you and be thrown into the sea”; R.T. France, The Gospel of Matthew, s. 790); T.J. Geddert, Mark, s. 265; R.H. Gundry („be lifted up and be thrown”; R.H. Gundry, Mark, s. 651-652); C.W. Hedrick („be taken up and cast into the sea”; C.W. Hedrick, On Moving Mountains, s. 224.236); M.D. Hooker („Be taken up and hurled into the sea"; M.D. Hooker, A Commentary on The Gospel according to St. Mark, s. 269); W.L. Lane („Be thou taken up and cast into the sea”; W.L. Lane, The Gospel according to Mark, s. 408); C.S. Mann („Be it lifted from your place and be thrown into the sea”; C.S. Mann, Mark. A New Translation with Introduction and Commentary, s. 451); J. Marcus („Be lifted up and cast inot the sea”; J. Marcus, Mark 8-16, s. 781); L. Morris („Be taken up and thrown into the sea"; L. Morris, The Gospel according to Matthew, s. 529); B.M. Newman („Be taken up and cast into the sea”; B.M. Newman, Matthew, s. 651); J. Nolland („Be lifted up and thrown into the sea"; J. Nolland, The Gospel of Matthew, s. 849.852); A. Yarbro Collins („Be lifted up and thrown into the sea”; A. Yarbro Collins, Mark, s. 522).

27 Zob. B.M. Newman, Matthew, s. 651.

28 Zob. R.G. Bratcher, E.A. Nida, Mark, s. 355.

29 D.B. Wallace, Greek Grammar Beyond the Basics. W ten sam sposób został przetłumaczony również tekst Mt 21,21 przez: D.A. Hangera („Be raised up and cast into the sea”; D.A. Hanger, Matthew 14-28, s. 603), D.J. Harringtona („Be taken up and cast into 
kai blēthēti. Żadna inna składnia greki biblijnej nie poświęca tym słowom uwagi, co świadczy jednoznacznie, że dla wszystkich innych uczonych zajmujących się syntaksą greki biblijnej formy te nie sprawiają żadnej trudności. Są po prostu imperatywami strony biernej aorystu. D.B. Wallace twierdzi jednak, pomimo opinii wszystkich innych badaczy, że istnieje w grece nowotestamentalnej tryb rozkazujący oświadczenia. Jego zdaniem, imperatyw w stronie pasywnej jest czasami odpowiednikiem - równoważnikiem stwierdzenia, które wyraża, że jakaś czynność jest spełniona w momencie, w którym się o niej mówi. Występuje on zawsze w stronie pasywnej i nie może być wykonany przez odbiorcę rozkazu. Ten rodzaj składniowy trybu rozkazującego używany jest, zdaniem D.B. Wallace'a, w celach retorycznych ${ }^{30}$.

Wyjaśnienie przedstawione przez D.B. Wallace’a nie jest jednak przekonujące. Po pierwsze, jedynie on przyjmuje istnienie tego rodzaju imperatywu strony biernej. Po wtóre, sprawia ono wrażenie, że zostało tak opracowane i sformułowane, aby uzasadnić translację form arthèti kai blēthèti występujących w Mk 11,23 i Mt 21,21 za pomocą strony zwrotnej, a nie biernej. Również inne przykłady użycia imperatywu oświadczenia podane przez D.B. Wallace’a (zob. Mk 1,41; 7,34; 11,23 i Rz 11,10) nie są przekonujące, ponieważ wskazane przez niego formy trybu rozkazującego strony biernej mogą być oddane za pomocą tej strony i niekoniecznie trzeba uciekać się do wyimaginowanej przez niego kategorii składniowej imperatywu, aby w sposób zrozumiały przetłumaczyć powyższe teksty. Co więcej, w podanych przez niego przykładach występowania imperatywu oświadczenia strona bierna form tego trybu powinna być przełożona nie za pomocą strony zwrotnej, lecz biernej. Wskazuje na to treść i przesłanie teologiczne owych tekstów. Wymownym przykładem jest pierwszy $\mathrm{z}$ nich, w którym forma kahtaristhèti (imperativus aoristi passivi 2. osoby liczby pojedynczej - „zostań oczyszczony”) nie może zostać przetłumaczona za pomocą strony zwrotnej („oczyść się”), ponieważ żaden człowiek nie może sam siebie oczyścić. Może to uczynić jedynie Bóg, co wyraża strona bierna (passivum theologicum).

the sea”; D.J. Harrington, The Gospel of Matthew, s. 296), U. Luza („Be taken up and cast into the sea"; U. Luz, Matthew 21-28, s. 21).

30 „Occasionally an imperative in the passive voice is the equivalent of a statement that is fulfilled at the moment of speaking. Such usage is reserved for passives that cannot be fulfilled by the recipient of imperative. On the surface, it looks like a command, but its nature is such that it cannot be obeyed by the recipient and yet it comes true at the moment it is uttered. The pronouncement (or, performative statement) is couched in imperatival terms for rhetorical effect" (D.B. Wallace, Greek Grammar Beyond the Basics, 492). Istnienie tego rodzaju imperatywu D.B. Wallace potwierdza w przypisie nr 109 na s. 440. 
Słuszność naszego zarzutu wobec oddania formy arthēti $\mathrm{w}$ znaczeniu zwrotnym potwierdza analiza form strony biernej airō występujących w tekście greckim Nowego Testamentu. Wszystkie formy tej strony wspomnianego czasownika posiadają znaczenie bierne ${ }^{31}$. Nigdy żadna $\mathrm{z}$ nich nie zachowuje się tak, jakby była czasownikiem posiadającym znaczenie strony medialnej. To samo można powiedzieć także o użyciu strony biernej czasownika ballōin Potwierdzają to wszystkie słowniki greki biblijnej ${ }^{33}$. Jednak słowniki greki klasycznej wskazują, że formy strony biernej czasownika airō mogą być tłumaczone przy użyciu strony zwrotnej „podnosić się"34. Znaczenie to jest jednak spotykane w grece klasycznej wyjątkowo rzadko, co więcej odnosi się ono jedynie do ciał niebieskich. Trudno podejrzewać, aby Marek i Mateusz znali klasyczne użycie strony biernej tego czasownika. Można przypuszczać jednak, że współcześni translatorzy tekstu biblijnego, mając do dyspozycji doskonałe słowniki języka greckiego, nadali biblijnej formie arthèti znaczenie, jakie może ona przybierać w grece klasycznej. Pozostaje jednak problem strony biernej formy blèthêti. Nigdy, nawet w grece klasycznej, formy strony biernej tego czasownika nie przybierają znaczenia zwrotnego ${ }^{35}$. Co sprawia, że w analizowanych przez nas tekstach również arthēti powinniśmy interpretować jako formę strony biernej. Najprawdopodobniej blēthēti zostało przetłumaczone za pomocą strony zwrotnej pod wpływem oddania przy użyciu właśnie tej strony formy arthēti, tak aby zachować spójność przekładu, ponieważ absurdalnym byłaby translacja: „podnieś się i zostań rzucona do morza”. Koherencja tłumaczenia wymaga oddania obu form w ten sam sposób.

Stronę bierną obu czasowników potwierdza także przekład Vuglaty, która analizowane przez nas słowa oddaje za pomocą: „Tollere, et mittere in mare” (Bibliorum Sacrorum Nova Vulgata Editio). Tollere i mittere są imperatywa-

31 Zob. arthēsetai w Mt 13,12; 21,43; 25,29; Mk 4,25; Łk 8,18; 19,26; èrthē w Łk 9,17; Dz 8,33; 20,9; airomen w Mk 2,3; arthōsin w J 19,31; érmenon w J 20,1; airetai w Dz 8,33; arthē $[i]$ w 1 Kor 5,2 i arthētō w Ef 4,31.

32 Zob. Mt 3,10; 5,13.25.29; 6,30; 7,19; 8,6.14; 9,2; 13,47; 18,8.9; Mk 7,30; 9,42.45.47; Łk 3,9; 12,28; 16,20; 23,19.25; J 3,24; 12,6; 13,2.6; Ap 8,7.8; 12,9.9.9.10.13; 18,21; 19,20; 20,10.14.15.

33 Zob. np. W. Bauer, A Greek-English Lexicon of the New Testament and Other Early Christian Literature, s. 24.130-131; R. Popowski, Wielki słownik grecko-polski Nowego Testamentu, s. 14.90; C. Rusconi, Vocabolario del greco del Nuovo Testamento, s. 9.61-62.

34 Zob. F. Montanari, Vocabolario della lingua greca, s. 100. Jednak H.G. Liddell, R. Scott, A Greek-English Lexicon, s. 27 nie potwierdza tego znaczenia.

35 Zob. H.G. Liddell, R. Scott, A Greek-English Lexicon, s. 304-305; F. Montanari, Vocabolario della lingua greca, s. 412-413. 
mi strony biernej, stanowią więc dosłowne tłumaczenie oryginalnego tekstu greckiego.

Z dokonanych przez nas analiz wynika jednoznacznie, że nie ma podstaw do tłumaczenia form strony biernej (arthèti i blèthèti) za pomocą strony zwrotnej, jak to uczynili wszyscy translatorzy tekstu greckiego Mk 11,23 i Mt 21,21 na język polski. Być może uzasadnienia przekładu arthēti i blèthèti w Mk 11,23 i Mt 21,21 za pomocą strony zwrotnej powinniśmy szukać w Mt 17,20: amēn gar legō hymin: ean echēte pistin hōs kokkon sinapeōs, eirete tō [i] orei toutō [i]: metaba enthen ekei, kai metabesetai ${ }^{36}$. Imperatyw skierowany do góry w wersecie tym (metaba) jest wyrażony w stronie czynnej, zaś wypełnienie go (metabēsetai) w stronie medialnej. Nie możemy wykluczyć, że właśnie ten tekst wpłynął na tłumaczenie za pomocą strony zwrotnej na język polski słów, które są przedmiotem naszych analiz.

Pomimo tej możliwości powinniśmy jednak ocenić przekład słów arthēti i blēthēti za pomocą strony zwrotnej jako niewłaściwy, błędny oraz pozbawiony podstaw leksykalnych i składniowych.

\section{Analogia w Łk 17,6}

Tekst analogiczny do Mk 11,23 i Mt 21,21 odnajdujemy w Łk 17,6: eipen de ho kyrios: ei echete pistin hōs kokkon sinapeōs, elegete an tē [i] sykaminō[i] [tautē[i]]: ekridzōthèti kai fyteuthēti en tē[i] thalassē[i]; kai hypēkousen an hymin. Zdaniem C.W. Hedricka, Łk 17,6 jest wariantem tradycyjnego powiedzenia, które jednak jest odmienną wersją od logionu zawartego w Mk 11,23/Mt 21,21 ${ }^{37}$.

Również kontekst najbliższy tego wersetu, podobnie jak Mk 11,23 i Mt 21,21, mówi o wierze. W Łk 17,5 apostołowie proszą Jezusa, aby wzmocnił (prothes) ich wiarę. Analizowany przez nas werset $(€ \mathrm{k} \mathrm{17,6)}$ jest odpowiedzią Jezusa na tę prośbę uczniów ${ }^{38}$.

Werset ten posiada również podobną budowę do Mk 11,23 i Mt 21,21: wprowadzenie, które jest jednak mniej uroczyste (eipen de ho kyrios), i następująca po nim jego główna część. Posiada ona formę zdania warunkowe-

36 Zob. J. Zmijewski, Der Glaube und Seine Macht, s. 85-86.

37 Zob. C.W. Hedrick, On Moving Mountains, s. 224.

38 Zob. J.D.M. Derret, Moving Mountains and Uprooting Trees (Mk 11:22; Mt 17:20, 21:21; Lk 17,6), s. 240; C.W. Hedrick, On Moving Mountains, s. 224; J. Zmijewski, Der Glaube und Seine Macht, s. 83. 
go mieszanego ${ }^{39}$, w którym zawarte jest w formie mowy niezależnej wezwanie skierowane do morwy: ekridzōthèti kai fyteuthēti en tēe [i] thalassē[i]. W Łk 17,6 w porównaniu z Mk 11,23 i Mt 21,21 dostrzegamy trzy zasadnicze różnice. Po pierwsze, zdanie warunkowe w tekście Łukaszowym jest o wiele bardziej skomplikowane z punktu składni języka greckiego niż u Marka i Mateusza. Łk 17,6, podobnie jak tekst Markowy, jest rozbudowanym zdaniem warunkowym, które posiada dwa poprzedniki i odnoszący się do nich obu następnik ${ }^{40}$. Jednak pierwszy poprzednik posiada formę charakterystyczną dla zdań warunkowych typu realis, forma zaś drugiego poprzednika i następnika są charakterystyczne dla zdań warunkowych typu irrealis ${ }^{41}$, przy czym w drugim poprzedniku występuje forma imperfectum, zaś w następniku forma aorystu, co z punktu widzenia składni tego typu zdań warunkowych jest zaskakujące.

W porównaniu z Mk 11,23 i Mt 21,21 w Łk 17,6 odmienny jest przedmiot, do którego zwrócone są słowa wyrażające wiarę. W Mk i Mt była nim góra, zaś w Łk jest nim morwa ${ }^{42}$. Zmiana podmiotu spowodowała również zmianę słów skierowanych do niego. Nie jest to już arthēti kai blèthēti („zostań podniesiona i zostań rzucona”), lecz ekridzōthēti kai fyteuthēti („zostań wyrwana z korzeniami i zostań posadzona") ${ }^{43}$, choć miejsce, do którego oba podmioty mają zostać przemieszczone jest identyczne - „morze” (thalassa). Pomimo iż Łukasz w analizowanym przez nas tekście ze wskazanych powodów użył innych czasowników, to jednak nadał im tę samą formę, którą posiadają arthèti kai blēthēti. Również ekridzōthèti kai fyteuthèti są imperatywami aorystu strony biernej i dlatego tłumaczenie tych słów powinno brzmieć: „zostań wyrwana

39 Zob. A.T. Robertson, A Grammar of the Greek New Testament in the Light of Historical Research, s. 921.1015.1022.

40 J. Zmijewski twierdzi, że zdanie warunkowe posiada inną budowę. Według niego składa się ono z jednego poprzednika (ei echete) i dwóch następników (elegete an ... kai hypēkousen an) (zob. J. Zmijewski, Der Glaube und Seine Macht, s. 83).

41 Zob. J. Nolland, Luke 9:21-18:34, s. 838; M. Wolter, Das Lukasevengelium, s. 567.

42 Zob. Zmijewski, Der Glaube und Seine Macht, s. 83.

43 Zob. C.W. Hedrick, On Moving Mountains, s. 229. J.D.M. Derret, nawiązując do zmiany czasowników w Łk 17,6, wskazuje jako możliwe źródło tej zmiany niektórych rabinów pochrześcijańskich, którzy ze względu na ich interpretację Pisma Świętego byli nazywani „wyrywającymi z korzeniami góry”. Zaznacza jednak, że trudno jest stwierdzić, czy owi rabini nawiązywali do słów Jezusa i w ogóle skąd Jezus zaczerpnął ideę przeniesienia góry. Wskazuje Ps 18,7-8, Ez 38,20, Hi 28,9 bądź Za 14,4 jako możliwe ich źródło (zob. J.D.M. Derret, Moving Mountains and Uprooting Trees [Mk 11:22; Mt 17:20, 21:21; Lk 17,6], s. 232-233). 
z korzeniami i zostań posadzona" ${ }^{44}$, a nie „wyrwij się i przesadź się"45. J. Reiling i J.L. Swellengrebel twierdzą, nie podając jednak żadnego uzasadnienia, że pomimo iż obie formy czasownikowe są wyrażone w stronie biernej, to powinny być rozumiane jako formy strony zwrotnej ${ }^{46}$.

Tłumacze Łk 17,6 na język polski postąpili podobnie jak w przypadku Mk 11,23 i Mt 21,21, tzn. formy strony biernej oddali za pomocą strony zwrotnej:

„Pan rzekł: «Gdybyście mieli wiarę jak ziarnko gorczycy, powiedzielibyście tej morwie: 'Wyrwij się z korzeniem i przesadź w morze', a byłaby wam posłuszna»" (Biblia Tysiąclecia);

„A Pan powiedział: 'Gdybyście mieli wiarę jak ziarnko gorczycy i powiedzielibyście temu krzewowi morwy: "Wyrwij się i przenieś do morza», to by was posłuchał" (Biblia Paulistów);

„Pan zaś rzekł: Gdybyście mieli wiarę jak ziarnko gorczycy i powiedzieli tej morwie: Wyrwij się z korzeniami i przesadź się w morze - będzie wam posłuszna” (Biblia Poznańska);

44 Poprawnie ten tekst tłumaczą J.B. Green („Be uprooted and planted in the sea”; J.B. Green, The Gospel of Luke, s. 610), L.T. Johnson („Be uprooted and planted in the sea”; L.T. Johnson, The Gospel of Luke, s. 257), A.A. Just („Be uprooted and planted in the sea”; A.A. Just, Luke 9:51-24:53, s. 639), F. Mickiewicz („Zostań wyrwana i przesadzona w morze"; F. Mickiewicz, Ewangelia według św. Łukasza. Rozdziały 12-24, s. 217.222), I.H. Marshall (I.H. Marshall, The Gospel of Luke, s. 644), J. Nolland („Be uprooted and planted in the sea”; J. Nolland, Luke 9:21-18:34, s. 835), J. Radermakers i P. Bossuyt („Sii sradicato e sii piantato nel mare"; J. Radermarkers, P. Bossuyt, Lettura pastorale del Vangelo di Luca, s. 70), J. Reiling i J.L. Swellengrebel („Be uprooted and be planted in the sea”; J. Reiling, J.L. Swellengrebel, A Translator's Handbook on the Gospel of Luke, s. 579), L. Sabourin („Sii sradicato e trapiantato nel mare”; L. Sabourin, Il Vangelo di Luca, s. 284).

45 W ten sposób tłumaczą: J.D.M. Derret (zob. J.D.M. Derret, Moving Mountains and Uprooting Trees [Mk 11:22; Mt 17:20, 21:21; Lk 17,6], s. 240); W. Eckey („Entwurzele dich und pflanze dich ins Meer"; W. Eckey, Das Lukasevengelium. Unter Berücksichtigung seiner Paralleln. Teilband 2: Lk 11,1-24,53, s. 734), J. Ernst („Sradicati e trapiantati nel mare”; J. Ernst, Il Vangelo secondo Luca. Volume secondo: Luca 9,51-24,53, s. 676), E. Klostermann (zob. E. Klostermann, Das Lukasevengelium, s. 172), G. Nolli („Sràdicati e trapiàntati in mare”; G. Nolli, Evangelo secondo Luca, s. 752), G. Rossé („Sradicati e piantati nel mare”; G. Rossé, Il Vangelo di Luca, s. 651), G. Schneider („Entwurzle dich und verpflanze dich ins Meer”; G. Schenider, Das Evangelium nach Lukas. Kapitel 11-24, s. 347), W. Wiefel („Entwurzele dich und pflanze dich ins Meer"; W. Wiefel, Das Evangelium nach Lukas, s. 301), M. Wolter („Entwurzele dich und pflanze dich ins Meer”; M. Wolter, Das Lukasevengelium, s. 564). Podobnie tłumaczy analizowane przez nas słowa F. Gryglewicz: „Wyjdź z korzeniami i zacznij rosnąć w morzu" (F. Gryglewicz, Ewangelia według św. Łukasza, s. 273).

46 Zob. J. Reiling, J.L. Swellengrebel, A Translator's Handbook on The Gospel of Luke, s. 579. 
„Powiedział zaś Pan: Jeśli macie wiarę jak ziarno gorczycy, powiedzieliście by morwie [tej]: Wykorzeń się i zasadź się w morzu. I posłuszna była by wam” (Wydanie Interlinearne; red. R. Popowski - M. Wojciechowski);

„A Pan odpowiedział: Jeżeli będziecie mieli wiarę nawet taką tylko, jak ziarnko gorczycy, to gdy powiecie temu oto drzewu sykomory, żeby wyszło stąd z korzeniami i przeniosło się do morza, to was usłucha" (Biblia warszawsko-praska);

„Pan zaś odpowiedział: Gdybyście mieli wiarę jak ziarnko gorczycy i powiedzieli do morwy: Wyrwij się z korzeniami i przesadź do morza - byłaby wam posłuszna” (Pismo Święte Nowego Testamentu i Psalmy. Przekład ekumeniczny);

„A Pan rzekł: Jeślibyście mieli wiarę jak ziarno gorczycowe, i rzeklibyście do tego figowca: Wyrwij się z korzeniami i przesadź się w morze, usłuchałoby was" (Wydanie Brytyjskiego i Zagranicznego Towarzystwa Biblijnego) ${ }^{47}$.

Ewangeliczny przekład interlinearny Biblii tłumaczy zaś ten werset w następujący sposób: „Powiedział zaś Pan: Jeśli mieliście wiarę jak ziarno gorczycy, mówilibyście (kiedy)kolwiek morwie tej: zostań wykorzeniona zostań zasadzona w morzu i okazała posłuszeństwo (kiedy)kolwiek wam”.

Również w przypadku tłumaczenia Łk 17,6 nie można dostrzec żadnej przyczyny, dla której formy trybu rozkazującego strony biernej miałyby zostać oddane na język polski za pomocą strony zwrotnej.

\section{Konsekwencje teologiczne niewłaściwego tłumaczenia}

Tłumaczenie za pomocą strony zwrotnej („podnieś się i rzuć się”) słów arthēti kai blèthèti wypacza tekst oryginalny nie tylko na poziomie językowym - składniowym, ale również teologicznym. Zrealizowanie słów skierowanych do góry jest wyrazem głębokiej i żywej wiary, która, jeśli ktoś rzeczywiście wierzy całym swym sercem i nie wątpi, może nawet przenieść górę. Jest to hiperbola ${ }^{48}$, która mówi, że dzięki wierze, człowiek, modląc się, może dokonać rzeczy niemoż-

47 W podobny sposób werset ten przetłumaczony został przez Pismo Święte w Przekładzie Nowego Świata (wydanie Biblii dokonane przez świadków Jehowy na podstawie New Word Translation of the Holy Scriptures).

48 Zob. T.J. Geddert, Mark, s. 265; H. Langkammer, Ewangelia według św. Marka, s. 268. Tej interpretacji sprzeciwia się M.E. Boring: „'Faith that moves mountains' is not a general hyperbolic proverb about the power of faith, but is related to 'this mountain', which probably refers to the temple mountain - the subject of the whole section" (M.E. Boring, Mark, s. 324). Por. C.A. Evans, Mark 8:27-16:20, s. 189; D.A. Hanger, Matthew 14-28, s. 606. 
liwych i nadzwyczajnych ${ }^{49}$. Jaki jest jednak wydźwięk i jakie przesłanie niesie ze sobą przekład tekstu greckiego na język polski za pomocą strony zwrotnej? Wiarę w kogo wyraża powyższe niewłaściwe oddanie tekstu oryginalnego? W Boga czy w górę? Wydaje się, że raczej w górę, ponieważ to ona sama ma się podnieść i rzucić się do morza. Bóg w tym tłumaczeniu jest obecny, ale jakby na drugim planie (implicite), ponieważ mówi się o wierze, a ta w Biblii zawsze odnosi się do Niego (On jest jej przedmiotem). Nie jest On jednak bohaterem pierwszorzędnym w translacjach polskich analizowanych przez nas słów, które zostały oddane przy użyciu strony zwrotnej („Podnieś się i rzuć się w morze”). Jego obecność jest jedynie poniekąd założona. Jeśli góra ma się podnieść sama i rzucić się w morze, to czynności tych powinna dokonać ona sama. Góra więc, a nie Bóg, jest pierwszoplanową postacią tego wersetu w oddaniu go na język polski. Na poparcie naszej interpretacji możemy przytoczyć opinię J.D.M. Derreta, który twierdzi, że bluźnierstwem jest twierdzić, że człowiek może przenieść górę. Zgodnie z Hi 9,5 jedynie Bóg może tego dokonać („W mgnieniu oka On przesunie góry i zniesie je w swoim gniewie" $)^{50}$. Potwierdza to także E. Jezierska, pisząc: „W ST przenoszenie góry było dziełem Boga; tak wielką moc przypisywano Bogu. W NT, w ujęciu synoptyków, wiara, która może wielkie rzeczy zdziałać, łączy się ze ścisłą więzią człowieka z Bogiem, wyraża się w całkowitym zaufaniu Bogu, całkowitym i bezwarunkowym powierzeniu się Bogu [...]. Tylko taka wiara może cuda czynić" 51 .

Cytat ten potwierdza, że to nie człowiek sam, dzięki swojej wierze, może uczynić cud (rozkazać górze, aby się przeniosła do morza), ani tym bardziej sama góra nie jest w stanie się przenieść i rzucić do morza, ale że to jedynie Bóg jest tym, który może tego dokonać, jeśli tylko człowiek wierzy w Jego wszechmoc i z Nim współdziała, ufając Mu całkowicie ${ }^{52}$.

Tekst oryginalny zawiera dwa imperatywy aorystu w stronie biernej („zostań podniesiona i rzucona”), które z punktu widzenia składni języka greckiego powinniśmy określić jako passivum theologicum. Oznacza to, że podmiotem czynności wyrażonych przez arthèti kai blèthèti jest Bóg, to On ma dokonać

49 „Moving a mountain appears to have been a proverbial saying for doing difficult tasks" (M.D. Hooker, A Commentary on The Gospel according to St. Mark, s. 269). Por. C.W. Hedrick, On Moving Mountains, s. 223.

50 Zob. J.D.M. Derret, Moving Mountains and Uprooting Trees (Mk 11:22; Mt 17:20, 21:21; $L k$ 17,6), s. 231.

51 E. Jezierska, Jaka wiara może „góry przenosiç? (Mt 17,14-21 i par.), s. 358.

52 Zob. E. Jezierska, Jaka wiara może „góry przenosić”? (Mt 17,14-21 i par.), s. 360. 
podniesienia i rzucenia góry do morza ${ }^{53}$. Tekst grecki wyraźnie i jednoznacznie odnosi powyższe słowa do Boga, choć nie jest On wymieniony wprost. Potwierdza to M.E. Boring, twierdząc, że formy pasywne, które są przedmiotem naszych badań, nie świadczą o mocy wiary, czy mocy modlitwy, lecz o wszechmocy Boga, dla którego nic nie jest niemożliwe (por. Mk 9,23; 10,27) ${ }^{54}$. Naszym zdaniem, powyższa interpretacja lepiej oddaje przesłanie teologiczne analizowanego tekstu, ponieważ mówi wprost o działaniu Boga, choć Jego imię nie zostało wymienione w tekście. To właśnie On i Jego dzieła są przedmiotem wiary, o której mówi Pismo Święte ${ }^{55}$. Powyższą interpretację potwierdza wyraźnie i jednoznacznie wersja Markowa, która odnosi akt wiary do Boga. Najpierw czyni to poprzez wezwanie "miejcie wiarę w Boga” (Mk 11,22b). W 11,24 mowa jest o modlitwie, dzięki której wierzący, jeśli tylko naprawdę wierzy, może uczynić wszystko. Uczeń otrzyma dzięki modlitwie i poprzez nią wszystko, o co prosi, nawet góra może zostać przemieszczona i rzucona do morza. Modlitwy kierujemy jednak do Boga, a nie do góry ${ }^{56}$. Przemawia to za tym, iż podmiotem, który dokona tego niezwykłego dzieła, jest Bóg, a nie góra ${ }^{57}$. W Starym Testamencie jedynie On może sprawić, że góry się trzęsą, i On może uczynić z nich równinę ${ }^{58}$. Skoro wersja Markowa odnosi akt wiary - o którym mowa w Mk 11,23, a konkretniej słowa, które są przedmiotem naszej analizy do modlitwy ${ }^{59}$, to jednoznacznie wynika, że podmiotem, który ma dokonać czynności w nich wyrażonych, jest Bóg, nie góra ${ }^{60}$.

Podsumowując, możemy stwierdzić, że błąd, który pojawił się w przekładach na język polski Mk 11,23 i Mt 21,21, wypacza przesłanie teologiczne obu

53 Zob. T.J. Geddert, Mark, s. 265; R.H. Gundry, Mark, s. 651-652. „We have to do here with mountain removal rather than mountain moving, an activity with OT background. This motif accompanies the promised day of salvation as part of the transformation of the cosmos (e.g. Isa 40:3-5; 45:2; 49:11; cf. 54:10; Zech 14:4-5; Pss. Sol. 11:4; Bar 5:7)” (C.A. Evans, Mark 8:27-16:20, s. 189).

54 Zob. M.E. Boring, Mark, s. 325.

55 „It admit the one who has placed his faith totally in God into participation in God's redemptive, transforming activity of the day of salvation" (C.A. Evans, Mark 8:27-16:20, s. 189).

56 Zob. R.H. Gundry, Mark, s. 651.

57 Zob. C.A. Evans, Mark 8:27-16:20, s. 195; S. Grasso, Vangelo di Marco, s. 294-295; R.H. Gundry, Mark, s. 651.653.

58 Zob. S. Légasse, Marco, s. 588.

59 Zob. J. Delorme, L'heureuse annonce selon Marc, s. 263.

60 „C'est pourquoi il faut compter avec l'ouverture au tiers, à l'autre, qui apparaît sans être mis en figure, autant dans le passif des verbes 'sois enlevée' et 'sois jetée' que dans le fait de prier" (J. Delorme, L'heureuse annonce selon Marc, s. 264). 
tych tekstów i czyni go niejasnym. Poprawne zaś tłumaczenie, które oddaje stronę bierną słów będących przedmiotem naszych badań, czyni z jednej strony wyraźniejszym i bardziej zrozumiałym przesłanie dotyczące wiary, ponieważ odnosi zarówno te słowa, jak i akt wiary, które one wyrażają, do Boga. Z drugiej zaś - jest wiernym oddaniem na język polski tekstu oryginalnego. To samo możemy powiedzieć także o oddaniu na język polski tekstu Łk 17,6 (ekridzōthēti kai fyteuthēti en tē [i] thalassēe[i] - „zostań wyrwana z korzeniami i zostań posadzona w morzu”).

\section{Zakończenie}

Kończąc naszą analizę Mk 11,23, Mt 21,21 oraz Łk 17,6, musimy stwierdzić, że przesłanki składniowe, które uzasadniają oddanie na język polski imperatywów strony biernej za pomocą form trybu rozkazującego strony zwrotnej, istnieją, ale tylko w przypadku arthēti. Naszym zdaniem, są one jednak bardzo słabe i w obrębie greki biblijnej wręcz niemożliwe do przyjęcia (użycie klasyczne arthēti). Być może uzasadnieniem takiej translacji tekstu oryginalnego jest fakt, że analizowane przez nas słowa skierowane są bezpośrednio do góry, co może zakładać, że to ona ma dokonać czynności przez nie wyrażonych. Inną przyczyną może być dostosowanie tłumaczenia polskiego do zasad języka polskiego. Strona zwrotna brzmi bardziej naturalnie w przekładzie niż strona bierna, a może tylko jest to kwestia przyzwyczajenia się do takiego, a nie innego przekładu. Czy jednak poprawność języka powinna aż tak bardzo ingerować w przekład, że aż czyni tekst bezsensownym z punktu widzenia teologicznego? Raczej przesłanie teologiczne i wierność oryginałowi, a nie jedynie poprawność wypowiedzi w języku polskim, powinna być główną troską translatora tekstu natchnionego.

Trudno jest jednoznacznie wskazać, dlaczego wszystkie tłumaczenia polskie analizowanych przez nas słów użyły strony zwrotnej. Przyczyn, jak wskazaliśmy powyżej, może być wiele i najprawdopodobniej wszystkie miały wpływ na takie, a nie inne oddanie arthèti kai blèthèti na język polski.

Interesujących wyników dostarczają tłumaczenia analizowanych przez nas słów na inne języki nowożytne. Okazuje się bowiem, że zdecydowana większość przekładów angielskojęzycznych oddaje je za pomocą strony biernej (jedynie zaledwie kilka angielskojęzycznych przekładów Biblii oddaje je w znaczeniu strony zwrotnej), w większości translacji niemieckojęzycznych przeważa strona zwrotna (jedynie kilka oddaje je za pomocą strony biernej), natomiast wszystkie tłumaczenia na język francuski, włoski i hiszpański używają strony zwrotnej. Być może właśnie tu tkwi źródło przekładu analizowanych przez nas 
słów za pomocą strony zwrotnej na język polski. Jeśli rzeczywiście tak by było, to rodzi się pytanie odnoszące się do zapewnienia wydawców i translatorów, że opublikowany przez nich tekst Biblii na język polski jest tłumaczeniem oryginału greckiego Nowego Testamentu.

\section{Bibliografia}

Albrecht G.J., Albrecht M.J., Matthew, Milwaukee 1996.

Albright W.F., Mann C.S., Matthew. Introduction, Translation, and Notes, New Haven, London 2008.

Bauer W., A Greek-English Lexicon of the New Testament and Other Early Christian Literature, Chicago, London ${ }^{2} 1979$.

Beck T., Benedentti U., Brambillasca G., Clerici F., Fausti S., Una comunitá legge Il vangelo di Marco, Bologna 1978.

Blass F., Debruner A., Grammatica del greco del Nuovo Testamento, Brescia ${ }^{2} 1997$.

Blomberg C.L., Matthew, Nashville 1992.

Boice J.M., The Gospel of Matthew. Volume 2: The Triumph of the King. Matthew 18-28, Grand Rapids 2001.

Boring M.E., Mark. A Commentary, Luisville, London 2006.

Bratcher R.G., Nida E.A., Mark. Translator's Handbook on the Gospel of Mark, London 1961.

Carter W., Matthew and the Margins. A Socio-Political and Religious Reading, Sheffield 2000.

Cole R.A., Il Vangelo secondo Marco. Intorduzione e commentario, Roma 1989.

Crossan J.D., In Fragments: The Aphorisms of Jesus, San Francisco 1983.

Davies W.D., Allison D.C., The Gospel according to Saint Matthew III, Edinburgh 1997.

Delorme J., L'heureuse annonce selon Marc. Lecture intégrale du deuxième évangile II, Paris, Montréal 2008.

Derret J.D.M., Moving Mountains and Uprooting Trees (Mk 11:22; Mt 17:20, 21:21; Lk 17,6), Bibbia e Oriente 30 (1988), s. 231-244.

Duplacy J., La foi qui déplace les Montagnes (Mt., XVII, 20; XXI, 21 et par.), w: À la rencontre de Dieu. Mémorial Albert Gélin, ed. M. Jourjon, Mappus 1961, s. 273-287.

Eckey W., Das Lukasevengelium. Unter Berücksichtigung seiner Paralleln. Teilband 2: tk 11,1-24,53, Vluyn 2004.

Ellul D., Dérives autour d'un figuier: Matthieu 21,18-22, Foi et Vie 5 (1992), s. 69-76.

Ernst J., Il Vangelo secondo Luca. Volume secondo: Luca 9,51 - 24,53, Brescia 1985.

Ernst J., Il Vangelo secondo Marco, Brescia 1991.

Evans C.A., Mark 8:27-16:20, Nashville 2001.

Fabris R., Matteo, Roma 1982.

France R.T., The Gospel of Matthew, Grand Rapids, Cambridge 2007.

Geddert T.J., Mark, Scottdale, Waterloo, 2001.

Gnilka J., Das Evangeliu nach Markus. 2 Teil Mk 8,27 - 16,20, Zürich 1979. 
Gnilka J., Das Matthäusevangelium. II Teil. Kommentar zu Kap 14,1-28,20 und Einleitungsfragen, Freiburg, Basel, Wien 1988.

Grasso S., Il Vangelo di Matteo, Roma 1995.

Grasso S., Vangelo di Marco, Milano 2003.

Green J.B., The Gospel of Luke, Grand Rapids, Cambridge 1997.

Gryglewicz F., Ewangelia według św. Łukasza. Wstęp - przekład z oryginału - komentarz, Poznań, Warszawa 1974.

Gundry R.H., Mark. A Commentary on His Apology for the Cross, Grand Rapids 1993.

Gundry R.H., Matthew: A Commentary on His Literary and Theological Art, Grand Rapids 1982.

Hahn F., Jesu Wort vom bergeversetzenden Glauben, ZNW 76 (1985), s. 149-169.

Hanger D.A., Matthew 14 - 28, Dallas 1995.

Harrington D.J., The Gospel of Matthew, Collegeville 1991.

Hedrick C.W., On Moving Mountains. Mark 11,22b-23/Matt 21,21 and Parallels, Forum 6 (1990), s. 219-237.

Homerski J., Ewangelia wedłu św. Mateusza. Wstęp - przekład z oryginału - komentarz, Poznań, Warszawa 1979.

Hooker M.D., A Commentary on The Gospel according to St. Mark, London 1991.

Jezierska E., Jaka wiara może „góry przenosić”? (Mt 17,14-21 i par.), w: Cierpliwość i miłość. Księga dla uczczenia Kardynała Henryka Gulbinowicza, E. Janiak, W. Irek (red.), Wrocław 2010, s. 353-360.

Johnson L.T., The Gospel of Luke, Collegeville 1991.

Just A.A., Luke 9:51 - 24:53, Sant Luis 1997.

Kernaghan R.J., Mark, Downers Grove, Nottingham 2007.

Klostermann E., Das Lukasevengelium, Tübingen ${ }^{3} 1971$.

Klostermann E., Das Matthäusevengelium, Tübingen 1971.

Langkammer H., Ewangelia według św. Marka. Wstęp - przekład z oryginału - komentarz, Poznań, Warszawa 1977.

Lane W.L., The Gospel according to Mark, Grand Rapids, Cambridge 1974.

Légasse S., Marco, Roma 2000.

Liddell H.G., Scott R., A Greek-English Lexicon, Oxford ${ }^{9} 1996$.

Luz U., Matthew 21 - 28. A Commentary, Minneapolis 1989.

Mann C.S., Mark. A New Translation with Introduction and Commentary, Garden City, New York 1986.

Marcus J., Mark 8-16. A New Translation with Introduction and Commentary, New Haven, London 2009.

Marshall I.H., The Gospel of Luke. A Commentary on the Greek Text, Grand Rapids 1978.

McKay K.L., A New Syntax of the Verb in New Testament Greek, New York 1994.

Meynet R., L'évangeli de Marc, Pendé 2014.

Mickiewicz F., Ewangelia według św. Łukasza. Rozdziały 12-24, Częstochowa 2012.

Montanari F., Vocabolario della lingua greca, Torino ${ }^{2} 2004$.

Nolli G., Evangelo secondo Luca, Cittá del Vaticano ${ }^{2} 1993$.

Nolli G., Evangelo secondo Marco, Cittá del Vaticano ${ }^{3} 1996$. 
Nolli G., Evangelo secondo Matteo, Cittá del Vaticano ${ }^{2} 1996$.

Morris L., The Gospel according to Matthew, Grand Rapids, Cambridge 1992.

Newman B.M., Matthew. A Handbook on the Gospel of Matthew, New York 1988.

Nolland J., Luke 9:21-18:34, Dallas 1993.

Nolland J., The Gospel of Matthew. A Commentary on the Greek Text, Grand Rapids 2005.

Paciorek A., Ewangelia według świętego Mateusza. Część II: Rozdziały 14-28, Częstochowa 2008.

Popowski R., Wielki słownik grecko-polski Nowego Testamentu, Warszawa ${ }^{4} 2006$.

Radermarkers J., Lettura pastorale del Vangelo di Matteo, Bologna 1974.

Radermarkers J., Bossuyt P., Lettura pastorale del Vangelo di Luca, Bologna 1981.

Reiling J., Swellengrebel J.L., A Translator's Handbook on The Gospel of Luke, New York 1971.

Robertson A.T., A Grammar of the Greek New Testament in the Light of Historical Research, Nashville 2010.

Rossé G., Il Vangelo di Luca. Commento esegetico e teologico, Roma 2001.

Rusconi C., Vocabolario del greco del Nuovo Testamento, Bologna 1997.

Ryken L., Wilhott J.C., Longman III T. (ed.), Le immagini bibliche. Simboli, figure retoriche e temi lettarari della Bibbia, Cisinello Balsamo 2006.

Sabourin L., Il Vangelo di Luca. Introduzione e Commento, Roma 1989.

Sand A., Das Evangelium nach Matthäus, Regensburg 1986.

Schenider G., Das Evangelium nach Lukas. Kapitel 11-24, Gütersloh 1997.

Schlier H., amēn, TDNT I, 335-338.

Schulz S., Q die Spruchquelle der Evangelisten, Zürich 1972.

Schweizer E., Das Evangelium nach Markus, Göttingen 1983.

Stein R.H., Mark, Grand Rapids 2008.

Yarbro Collins A., Mark. A Commentary, Minneapolis 2007.

Young R.A., Intermediate New Testament Greek. A Linguistic and Exegetical Approach, Nashville 1994.

Wallace D.B., Greek Grammar Beyond the Basics. An Exegetical Syntax of the New Testament, Grand Rapids 1996.

Wiefel W., Das Evangelium nach Lukas, Berlin 1988.

Wicke H.E., Mark, Milwaukee 1988.

de Witt Burton E., Syntax of the Moods and Tenses in New Testament Greek, Edinburgh ${ }^{3} 1898$.

Wolter M., Das Lukasevengelium, Tübingen 2008.

Zerwick M., Il greco del Nuovo Testamento, Roma 2010.

Zmijewski J., Der Glaube und Seine Macht. Eine traditionsgeschichtliche Untersuchung zu Mt 17,20; 21,21; Mk 11,23; Lk 17,6, w: Begegnung mit dem Wort. FS Heinrich Zimmermann, J. Zmijewski, E. Nellessen (Hrsg.), Bonn 1980, s. 81-101. 
